UDC 681.5:539.319

DOI: $10.25140 / 2411-5363-2018-4(14)-162-168$

\author{
Patrik Šarga, František Trebuña, Branislav Grejták
}

\title{
DESIGN OF CONTROL FOR THE DEVICE USING FOR THE DETERMINATION OF RESIDUAL STRESSES BY RING-CORE METHOD
}

Urgency of the research. Residual stresses in machine parts and constructions greatly affect their service life and reliability. They are introduced into the manufactured object at each production process and their level can change significantly due to the operation of the product. Their main risk lies in the fact that they add up to the external load and can be the cause of the failure of the construction. Residual stresses can not be determined by simulation methods. They can only be determined using experimental methods. One of these method is the Ring-Core method, the principle of which is to form an annular groove around the strain gauge. Creating of annular groove releases the internal stresses, which can be recorded by a strain gauge. The quality of the formed groove has a significant impact on the overall results of residual stress determination, so it is important to make it as accurate as possible. For this reason, it is necessary to have the most reliable device to form an annular groove.

Target setting. Our goal was to design the drive and control for the measuring device for milling the annular groove. This will make it possible to mill the annular groove more precisely, and the resulting residual stresses will be minimally affected by the inaccuracy of the groove.

Actual scientific researches and issues analysis. When designing the control of the device and preparing this paper, we took into account not only current sources - publications and papers dealing with the current state of existing measuring devices used for determining residual stresses by Ring-Core method, but - we also took into account our practical experience gained in numerous residual stress determinations by experimental methods.

Uninvestigated parts of general matters defining. A modified device requires thorough testing, which has not been implemented during the research for this paper.

The research objective. The goal of the research was to create a control for the existing mechanical measuring device used for creating annular groove for determining residual stresses by Ring-Core method.

The statement of basic materials. The original mechanical device was supplemented by actuators, which were designed to automate the movement in horizontal axes as well as in the vertical axis. Thanks to this, we have achieved greater precision when positioning the work tool above the center of the strain gauge. At the same time, the original equipment was completed with a servo motor that serves to drive the cutter. For all these elements, control by Programmable Logic Controller was proposed.

Conclusions. Our task was to design control for the original device used for residual stress measurement by the RingCore method. We needed to design drives to automate the device. For our needs, we decided to apply linear actuators selected according to the requested criteria. After designing of the electric drives and modifying of the original device, we proceeded to implement control by Programmable Logic Controller. After that, we created a control program in the Automation studio software. This modified measuring device is able to achieve a much higher precision of the annular groove milling, which makes it possible to deter-mine the residual stresses in the structures more precisely.

Keywords: residual stresses, Ring-Core method, control, actuator, servomotor, Programmable Logic Controller.

Fig.: 7. References: 10

The current state of the problem

Our aim was to modify the original device used to determine residual stresses by the RingCore method (Fig. 1) [1;2]. Residual stresses have a significant impact on the overall life of each construction. Therefore, they need to be given sufficient attention. Residual stresses can not be determined by simulation methods, they can only be determined by experiment. To make the experiment, a reliable measurement device is needed to get the most accurate measured values.

The original device had a relatively simple design, and since no electronic components were used, all processes were manually controlled [3]. This resulted in several disadvantages of this system.

Disadvantages of the original system:

- Manual positioning,

- Manual feed control in the vertical direction,

- Manual controlling of the rotation speed of the milling process,

- Significant impact of human factor.

\section{Design of components}

The main purpose of our design was to modify the original system so that it is possible to manage individual processes such as positioning and milling of the annual groove. For this purpose, actuators have been designed to provide positioning and drive for the milling cutter itself. For our needs, we have to consider the optimal type of drives according to the requirements. Addition of the actuators requires the modification of the original device. It was necessary to create a control unit capable of communicating with a personal computer. Finally, completing of the measuring chain was needed.

(C) Šarga P., Trebuňa F., Branislav G., 2018 


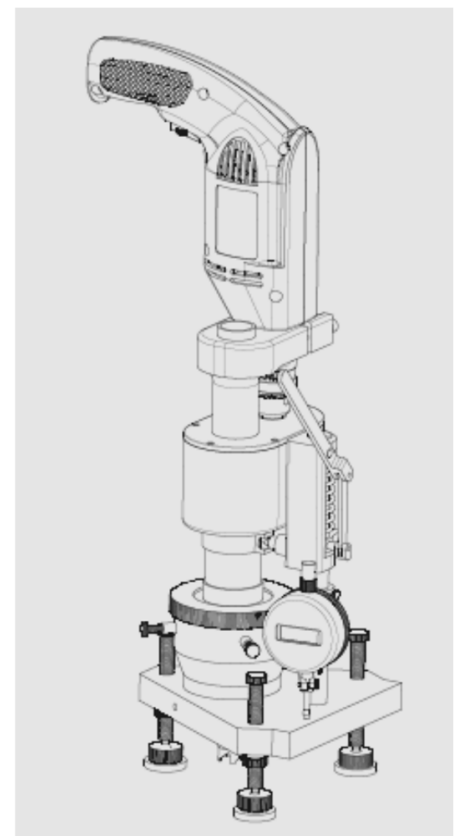

Fig. 1. Original design solution

Actuator requirements:

- Positioning accuracy,

- Repeatability of positioning,

- Sufficient load capacity,

- Sufficient movement range,

- Effectiveness of management,

- Low financial costs.

\section{Design of the drive in horizontal direction}

For the design, an electric drive was chosen whose accuracy ranges in $\mu \mathrm{m}$. The most suitable type of electric drive has proved to be a linear actuator, namely, we chose the CXS6050S2NN-ND [4]. Such an actor was used for positioning in $\mathrm{x}$ and $\mathrm{y}$ axes.

Actuator CXS6050-S2NN-ND is a linear drive type with single axis positioning. The maximum possible ejection is $50 \mathrm{~mm}$, which is sufficient, because only the fine positioning of the cutter will be realized in this way. The actuator's carrying capacity is $7 \mathrm{~kg}$, the weight carried will be $5.2 \mathrm{~kg}$. A positioning accuracy of $25 \mu \mathrm{m}$ is also sufficient. It is a two-step stepper motor and the supply voltage is $24 \mathrm{~V}$. The EE-SX498 optical sensor is also part of the actuator [4].

\section{Design of the drive in vertical direction}

In the next step it was necessary to solve the positioning of the device in the vertical direction. As in the previous case, we used a linear actuator, but it was necessary to create an additional structure that would allow the drive to be placed in the vertical direction. For vertical movement, we needed an actuator with a greater range of motion, so we chose the linear actuator CXN5075-S1VN-ND-P1 [5].

Again, this is a two-step stepper motor with $24 \mathrm{~V}$ supply and a load of $10 \mathrm{~kg}$. The accuracy for this type of device is reported at $0.25 \mu \mathrm{m}$, which is sufficient for our needs [5]. Locations suitable for attaching the actuator to the auxiliary construction have to be designed so that the actuator and the construction do not prevent positioning in the axes $\mathrm{x}$ and $\mathrm{y}$ Therefore, we placed the construction on a platform that is attached to an $\mathrm{x}$-axis actuator.

The next step was to fix the linear actuator to the original system. On the actuator, we connected the auxiliary piece with screws and we connected it to the top of the gearbox. In this way, we have ensured that it is also possible to position the device in the z-axis. The modified construction is visible in Fig. 2. 
TECHNICAL SCIENCES AND TECHNOLOGIES

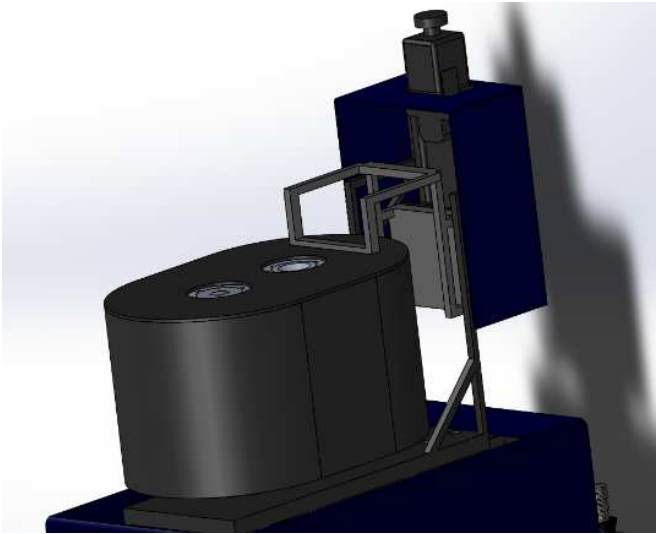

Fig. 2. Positioning mechanism in axis $z$

\section{Selection of the cutter drive}

The original device used a drill mounted in the rack as a drive, and the torque was transmitted through the gearing to the milling cutter. In principle, we designed a similar system, but not using a drill whose speed is controlled manually, but we used an electric motor controlled by a PLC. An important question was the type of electric drive. We have selected the B\&R 8LVA33.ee021ffgg-0 servo motor. It is a synchronous electric servo drive with selfcooling with a nominal speed of $2200 \mathrm{rpm}$ and the power of $539 \mathrm{~W}$ [6]. For the selected electric drive it was not necessary to change the structure of the device.

\section{Assembling of the device}

The original device was supplemented by two linear actuators designed to provide a horizontal displacement in the direction of the $\mathrm{x}$ and $\mathrm{y}$ axes. Due to the location of the individual electrical components, we had to adapt the original construction. We have placed three linear stepping motors for positioning in the vertical axis $(\mathrm{z})$ and two horizontal axes $(\mathrm{x}, \mathrm{y})$. We used a servo motor to drive the milling cutter itself, with which we transmit the torque through the gear. We put the engine in the casing together with the gear. The complete device is shown in Fig. 3. The working range of the device allows us to move $50 \mathrm{~mm}$ in the $\mathrm{x}$ axis direction and also $50 \mathrm{~mm}$ in the y-direction. A working range of $75 \mathrm{~mm}$ is available for $z$-axis positioning. The positioning accuracy in $\mathrm{x}$ and $\mathrm{y}$ axes is $15 \mu \mathrm{m}$ and $25 \mu \mathrm{m}$ in the $\mathrm{z}$-axis.

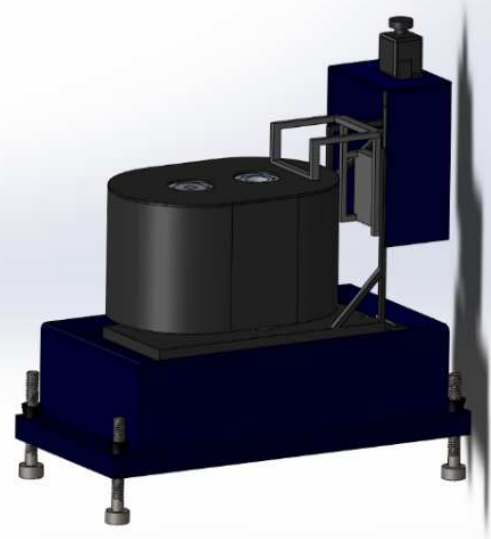

\section{Design of control unit}

Fig. 3. Final modified device

We have selected a Programmable Logic Controller (PLC) to control each element of the system. It is a small industrial computer that is used to automate industrial processes in real time. It is used in various branches of industry and automation. The difference between a microcomputer and PLC is that for a microcomputer, the length of the program depends on the number of commands, in the PLC it depends on the loop length setting and not on the number of commands in the loop [7;8]. 
TECHNICAL SCIENCES AND TECHNOLOGIES

We used the PLC 4PPC70.0702-20W, B\&R Modular Programmable Logic Controller. It is a device with a power panel and belongs to the $\mathrm{C}$-series. It has a touch-screen display, and works at a maximum work cycle speed of up to $1 \mathrm{~ms}$. The PLC has 256MB of RAM. 2GB of FLASH memory and the processor Intel E620T, which operates at 333MHz. [9]

For the system, we also used PowerLink, Ethernet, USB, and two X2X bus. Each connector has its specific role. Ethernet provides communication with PC. Via the X2X bus, other bus cards are connected to the bus controller.

Using the PowerLink connector, a bus controller is attached to the PLC to connect additional cards.

The bus controller has two PowerLink ports, one is connected to the PLC and the other to the servo driver. A servo driver is a device that contains a controller for drive control and is powered by $230 \mathrm{~V}$.

The last steps were to connect the PLC to the PC with an Ethernet connector and to set the correct IP address of the PC and the PLC. The complete control system is shown in Fig. 4.
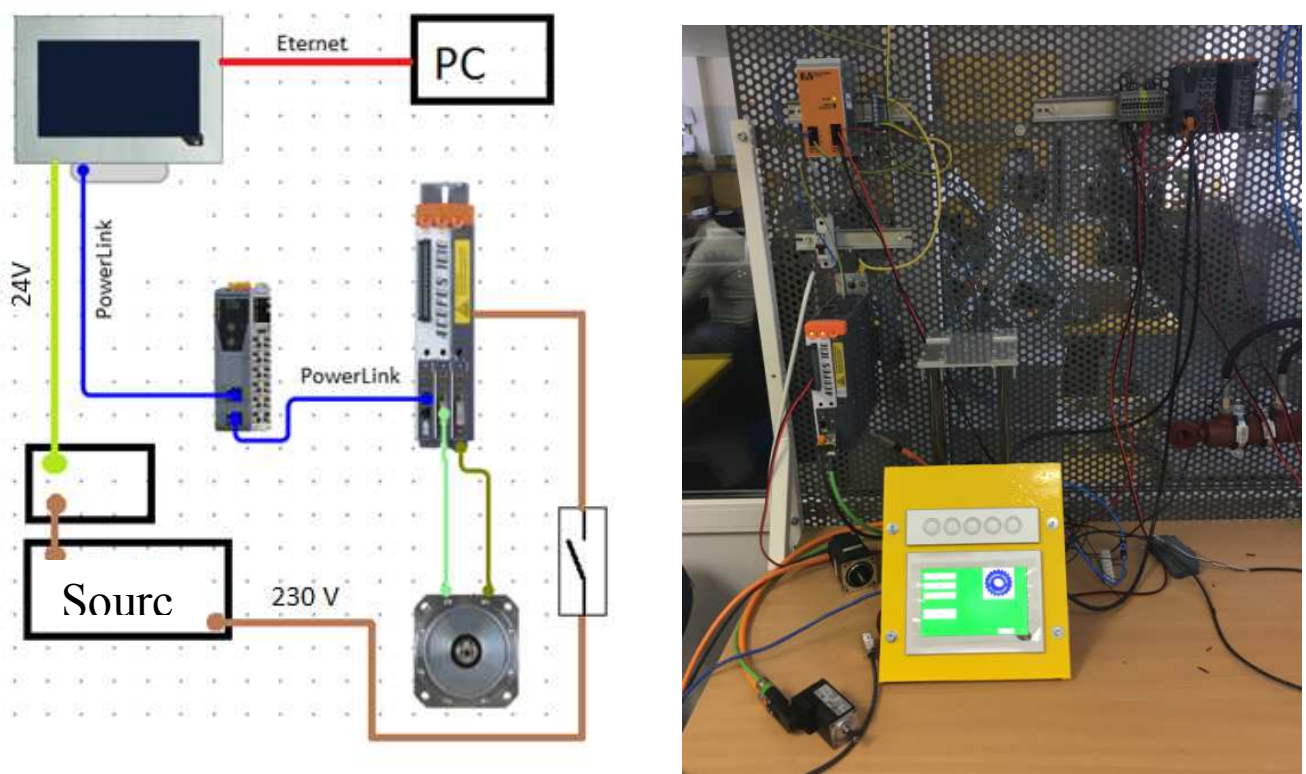

Fig. 4. Hardware Configuration

Software control was developed in Automation Studio 4. It is software designed for B\&R logic automation programming (Fig. 5) [10].
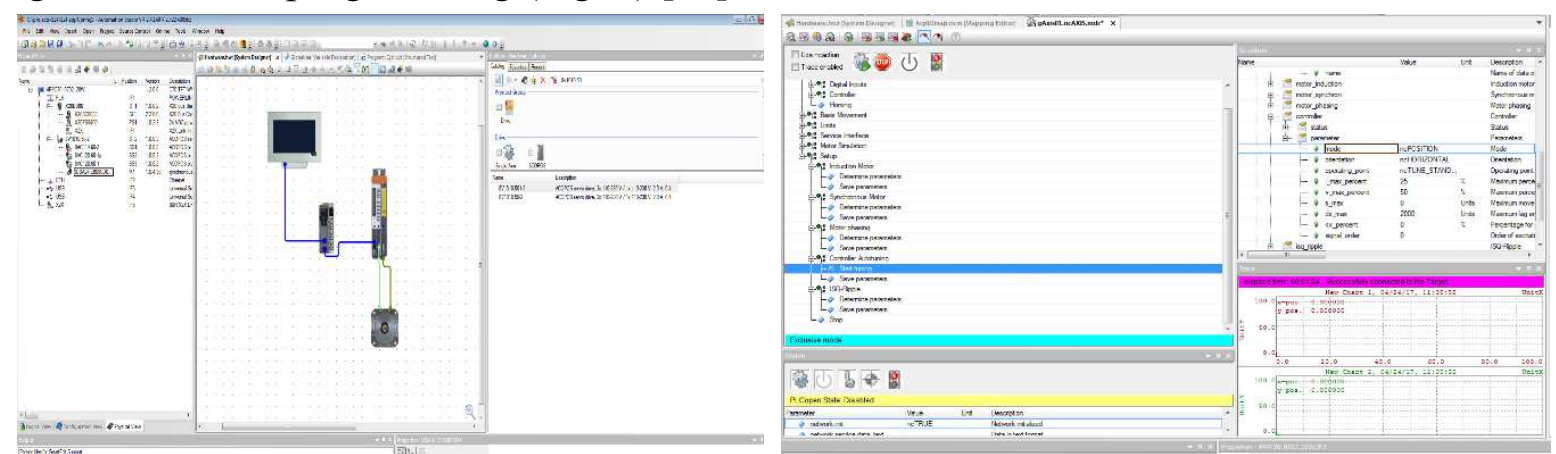

Fig. 5. Realization of control in the Automation Studio 4 software

In Fig. 6 we can see a preview of the created control program. 
TECHNICAL SCIENCES AND TECHNOLOGIES
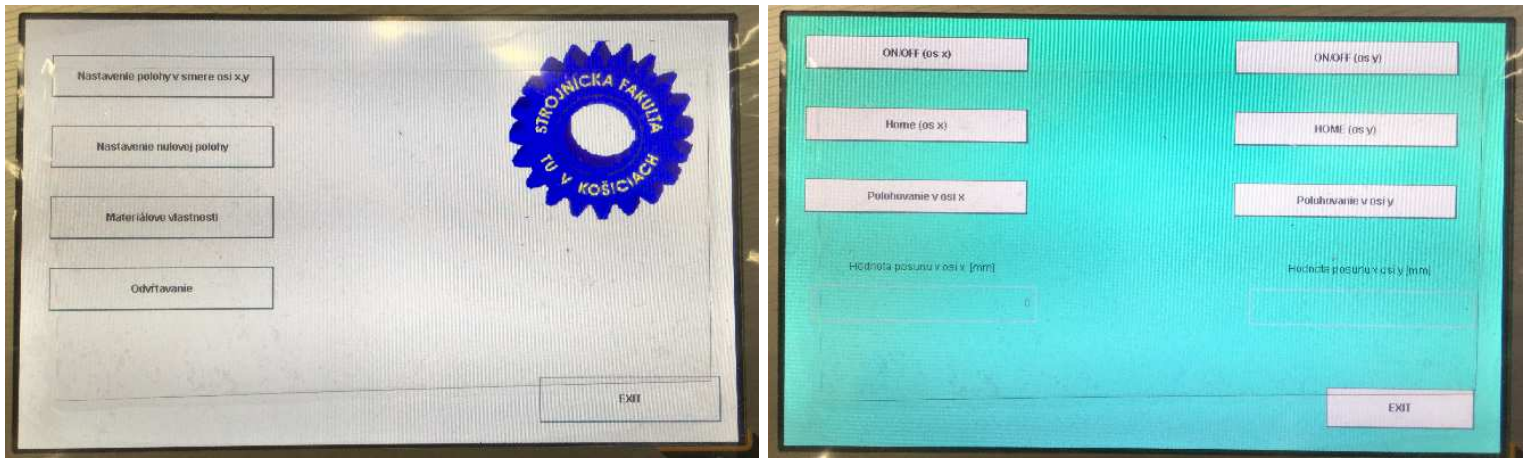

Fig. 6. Demonstration of the control program

\section{Finalization of the measurement chain}

The final step was to complete the measurement chain. We have added additional components to the modified measuring device with newly created control.

The final version of the measuring chain consists of the following components (Fig. 7):

- Measuring device,

- Control unit (PLC),

- QuantumX MX 840,

- QuantumX SCM-SG-120,

- Strain gauge RY 51,

- PC.

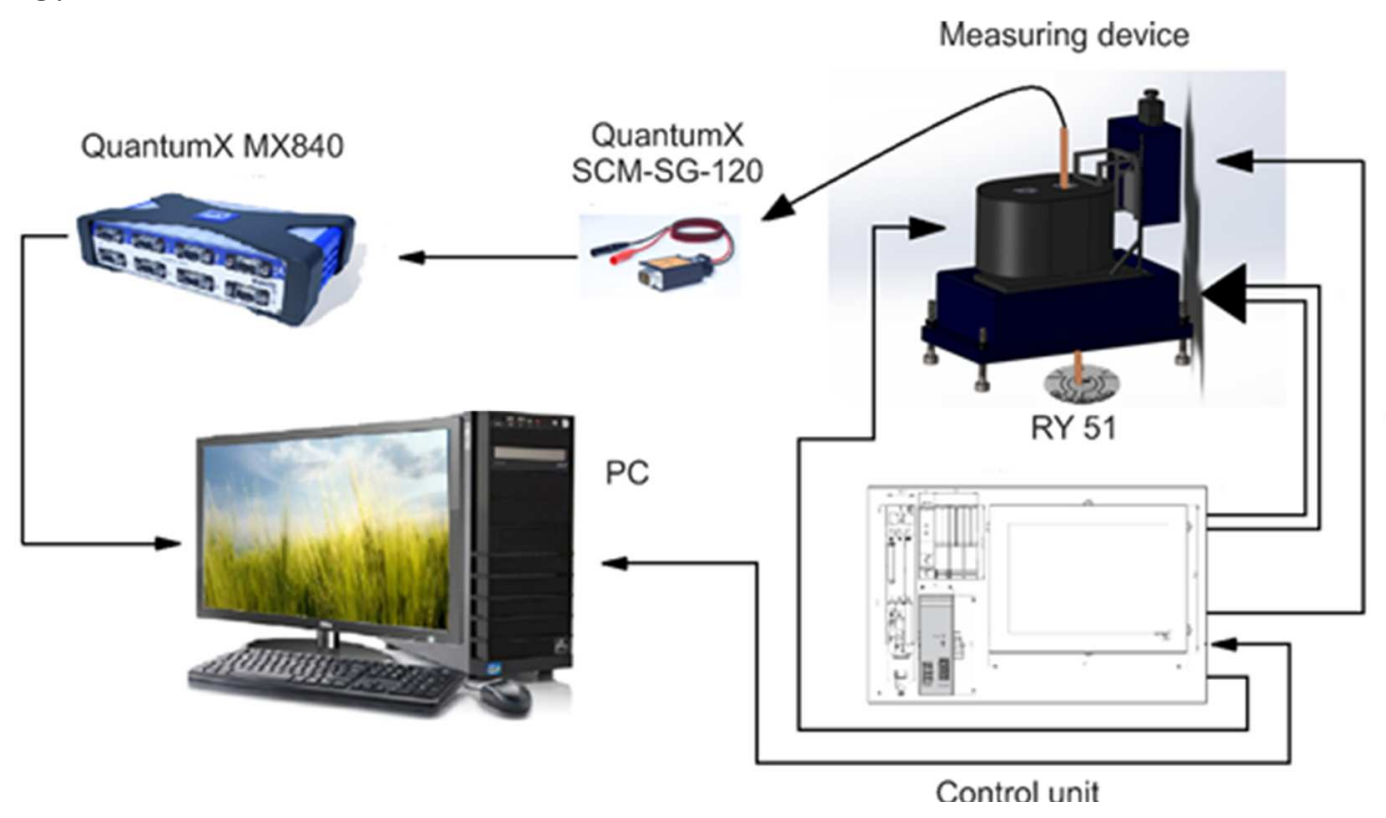

Fig. 7. Final measuring chain

\section{Conclusions}

Our task was to design control for the original device used for residual stress measurement by the Ring-Core method.

We needed to design drives to automate the device. For our needs, we decided to apply linear actuators selected according to the requested criteria. The advantage of these drives is their relatively simple control. For the drive of the cutter we used a $537 \mathrm{~W}$ servo motor.

After designing of the electric drives and modifying of the original device, we proceeded to implement PLC control, completed the components to control the selected drives and created a control unit. After that, we created a control program in the Automation studio software and we also designed visualization on PLC panels where we can control the operation of the device using the programmed buttons. 
TECHNICAL SCIENCES AND TECHNOLOGIES

The last part of the work was the completion of the measuring chain, which includes, in addition to the measuring device and the control unit, the QuantumX MX 840 measuring device with the necessary reduction to the SCM-SG-120 bridge, the RY 51 strain gauge and the PC.

Our improved automated measuring device is able to achieve much greater accuracy of ring groove milling, which makes determination of the residual stresses in the constructions more precise.

\section{Acknowledgement}

This work was supported by grant project KEGA 054TUKE-4/2016 Innovation of teaching courses with a focus on automation in response to the demands of industry and services and project VEGA 1/0751/16.

1. TREBUŇA, F., ŠIMČÁK, F. (2005) Kvantifikácia zvyškových napätí tenzometrickými metódami, Košice, ISBN 80-8073-227-2. [in Slovak]

2. RING CORE TECHNIQUE (2015). Retrieved from: http://www.veqter.co.uk/residual-stressmeasurement/ring-coring [in English].

3. GOMBITA, P. (2016): Návrh meracieho zariadenia slúžiaceho na určovanie zvyškových napätí pomocou metódy Ring-Core, Košice. [in Slovak]

4. GMT Europe, Linear actuator, Retrieved from: https://www.gmteurope.de/ index.php/products/standard-motorized-stage/linear-stage/cs-type/x-axis.html [in English]

5. GMT Europe, Precision motorized Stage, Retrieved from: https://www.gmteurope.de/ index.php/x-axis-5106.html [in English]

6. BR-Automation, 8LVA synchronous motors: Retrieved from: https://www.brautomation.com/en/products/motion-control/8lva-synchronous-motors/ [in English].

7. KOVÁ̌̆, J. a kol. (2015): Programování PLC, Praha. Retrieved from: http: http://www.spszl.cz/soubory/plc/programovani plc.pdf [in Czech].

8. MARČAN, P. (2017): 04 Základy PLC - Vol'ba konfigurácie: Daily Automation, Kysucké Nové Mesto, Retrieved from: http://dailyautomation.sk/volba-konfiguracie-plc/ [in Slovak]

9. Power Panel C70: Anwenderhandbuch (2015): Retrieved from: http://www.brautomation.com/ downloads_br_productcatalogue/BRP44400000000000000443060/MAPPC70-GER.1.10.pdf [in English].

10. Automation Studio: Perfection in Automation (2013): Eggelsberg, Austria, Retrieved from: http://we.pb.edu.pl/ files/Automation\%20Studio\%204.pdf [in English].

УДК 681.5:539.319

\section{Патрик Шарга, Франтишек Требуньа, Бранислав Грейтак}

\section{РОЗРОБКА СИСТЕМИ КЕРУВАННЯ ПРИСТРОЕМ ДЛЯ ВИЗНАЧЕННЯ ЗАЛИШКОВИХ НАПРУЖЕНЬ МЕТОДОМ КІЛЬЦЕВОЇ КАНАВКИ}

Актуальність теми дослідження. Залишкові напруження в деталях і конструкиіях машин сильно впливають на термін їх служби і надійність. Вони з'являються в об'єктах виробництва при кожному виробничому процесі, $і$ їх рівень може значно змінюватися в результаті роботи об'єкта. Їх основний ризик полягає в тому, ияо вони додаються до зовнішнього навантаження і можуть бути причиною відмови конструкції. Залишкові напруження не можуть бути визначені методами моделювання. Вони можуть бути визначені тільки з використанням експериментальних методів. Одним з таких методів є метод кільцевої канавки, принцип якого полягає у формуванні кільцевої канавки навколо тензодатчика. Створення кільцевої канавки знімає внутрішні напруження, які можуть бути записані тензодатчиком. Якість сформованої канавки робить істотний вплив на загальні результати визначення залишкових напружень, тому важливо зробити ї̈ якомога більш точною. 3 иієї причини необхідно мати найнадійніший пристрій для формування кільцевої канавки.

Постановка проблеми. Метою цієї роботи було розроблення привода й системи керування вимірювальним пристроєм для фрезерування кільцеевої канавки. Це дасть змогу більи точно фрезерувати кільцеву канавку, і результуючі залишкові напруження будуть мінімально залежні від похибки обробки канавки.

Аналіз останніх досліджень і публікацій. При розробичі системи керування пристроєм і підготовці иієё статті були враховані не тільки наявні джерела - публікачії та статті, присвячені існуючим вимірювальним приладам, які використовуються для визначення залишкових напружень методом кільцевої канавки, але також взято до уваги наш практичний досвід, отриманий у численних визначеннях залиикових напружень експериментальними методами.

Виділення недосліджених частин загальної проблеми. Модифікований пристрій вимагає ретельного тестування, яке не було реалізовано під час дослідження для иүієї статті. 
Постановка завдання. Метою дослідження було створення системи керування для існуючого механічного вимірювального пристрою, щуо використовується для створення кільцевої канавки для визначення залишкових напружень методом кільиевої канавки.

Виклад основного матеріалу. Існуючий механічний пристрій було доповнено виконавчими механізмами, які були розроблені для автоматизації руху по горизонтальній осі, а також по вертикальній осі. Завдяки цььому ми досягли більшої точності при розмішенні робочого інструмента над центром тензодатчика. Водночас існуюче обладнання було укомплектовано серводвигуном, який служить для приводу різия. Для всіх цих елементів було запропоновано управління за допомогою програмованого логічного контролера.

Висновки відповідно до статті. Нашим завданням було розробити систему керування вимірювальним пристроєм, що використовується для вимірювання залишкових напружень за методом кільиевої канавки. Нам потрібно було спроектувати привода для автоматизаиї пристрою. Для наших потреб ми вирішили використовувати лінійні приводи, обрані відповідно до необхідних критеріїв. Після проектування електроприводів $і$ модифікації існуючого пристрою ми приступили до реалізачії управління за допомогою програмованого логічного контролера. Після иього ми створили керуючу програму в програмному забезпеченні Aиtomation studio. Цей удосконалений вимірювальний пристрій дозволяє досягти набагато більи високої точності фрезерування кільцевих канавок, щчо дозволяє більи точно визначати залишкові напруження в конструкиіях.

Ключові слова: залишкові напруження; метод кільцевої канавки; управління; привод; серводвигун; Програмований логічний контролер.

Рис.: 7. Бібл.: 10

Patrik Šarga - Doctor of Technical Sciences, Associate Professor, Department of Automation, Control and Human

Machine Interactions, Faculty of Mechanical Engineering, Technical University of Košice, Letná 9 Košice, Slovakia.

E-mail: patrik.sarga@tuke.sk

Scopus Author ID: 15128102900

František Trebuňa - Doctor of Technical Sciences, Professor, Department of Applied Mechanics and Mechanical Engineering, Faculty of Mechanical Engineering, Technical University of Košice, Letná 9 Košice, Slovakia.

E-mail: frantisek.trebuna@tuke.sk

Scopus Author ID: 11239966000

Branislav Grejták - student of mechanical engineering, Faculty of Mechanical Engineering, Technical University

of Košice, Letná 9 Košice, Slovakia.

E-mail: branislav.grejtak@student.tuke.sk

Šarga, P., Trebuňa, F., Grejták, B. (2018). Design of control for the device using for the determination of residual stresses by ring-core method. Technical sciences and technologies, 4 (14), 162-168. 